\title{
Consumption of coffee associated with reduced risk of liver cancer: a meta-analysis
}

\author{
Li-Xuan Sang ${ }^{1}$, Bing Chang ${ }^{2}$, Xiao-Hang Li ${ }^{3}$ and Min Jiang ${ }^{2^{*}}$
}

\begin{abstract}
Background: Epidemiologic studies have reported inconsistent results regarding coffee consumption and the risk of liver cancer. We performed a meta-analysis of published case-control and cohort studies to investigate the association between coffee consumption and liver cancer.

Methods: We searched Medline, EMBASE, ISI Web of Science and the Cochrane library for studies published up to May 2012. We performed a meta-analysis of nine case-control studies and seven cohort studies.

Results: The summary odds ratio (OR) for high vs no/almost never drinkers was 0.50 (95\% confidence interval (Cl): $0.42-0.59)$, with no significant heterogeneity across studies $\left(Q=16.71 ; P=0.337 ; 1^{2}=10.2 \%\right)$. The ORs were 0.50 ( $95 \%$ Cl: $0.40-0.63)$ for case-control studies and 0.48 (95\% Cl: 0.38-0.62) for cohort studies. The OR was 0.38 (95\% Cl: $0.25-0.56$ ) in males and 0.60 (95\% Cl: $0.33-1.10$ ) in females. The OR was 0.45 (95\% Cl: $0.36-0.56)$ in Asian studies and 0.57 (95\% Cl: 0.44-0.75) in European studies. The OR was 0.39 (95\% Cl: $0.28-0.54)$ with no adjustment for a history of liver disease and 0.54 (95\% Cl: 0.46-0.66) after adjustment for a history of liver disease.
\end{abstract}

Conclusions: The results of this meta-analysis suggested an inverse association between coffee consumption and liver cancer. Because of the small number of studies, further prospective studies are needed.

Keywords: Coffee, Epidemiology, Liver cancer, Meta-analysis

\section{Background}

Primary liver cancer is a common malignancy worldwide. It is the fifth most common cancer in men and the cause of a third of male cancer deaths. It is the eighth most common cancer in women and the sixth most common cause of female cancer deaths [1]. Chronic infection with hepatitis $\mathrm{B}$ or $\mathrm{C}$ viruses and alcohol consumption are considered the most important risk factors for liver cancer [2-5]. A large number of epidemiological studies indicated that environmental factors can affect the risk of liver cancer, but the role of dietary factors in tumorigenesis has not yet been determined [6-8]. Analysis of environmental factors that may be associated with liver cancer has become a popular research topic in recent years.

Coffee contains many biologically active components, some of which may have anti-tumor effects. Epidemiological studies have reported inconsistent findings on the

\footnotetext{
*Correspondence: fendou1957@163.com

${ }^{2}$ Department of Gastroenterology, First Affiliated Hospital of China Medical University, No.155, Nanjing North Street, Heping District, Shenyang, Liaoning Province 110001, China

Full list of author information is available at the end of the article
}

association between coffee and liver cancer. We therefore carried out a meta-analysis of prospective cohort studies and case-control studies in order to clarify the association between coffee consumption and liver cancer.

\section{Methods \\ Search strategy}

We searched Medline (via PubMed; National Library of Medicine), EMBASE (Elsevier, Amsterdam, the Netherlands), ISI Web of Science (Institute for Scientific Information, Philadelphia, Pennsylvania), and the Cochrane library (Wiley, Chichester, United Kingdom) for studies published up to May 2012. Key words searched were as follows: (coffee OR caffeine OR beverages OR diet OR drinking OR lifestyle) AND (liver OR hepatocellular OR digestive) AND (cancer OR carcinoma OR tumor OR neoplasm) AND (risk). No language restrictions were applied.

\section{Inclusion and exclusion criteria}

The inclusion criteria were: case-control or cohort study; data on the frequency of coffee consumption; primary 
Table 1 Quality assessment of case-control studies included in this meta-analysis ${ }^{1}$

\begin{tabular}{|c|c|c|c|c|c|c|c|c|c|}
\hline Study & $\begin{array}{l}\text { Adequate } \\
\text { definition of } \\
\text { cases }\end{array}$ & $\begin{array}{l}\text { Representativeness } \\
\text { of cases }\end{array}$ & $\begin{array}{l}\text { Selection } \\
\text { of control }\end{array}$ & $\begin{array}{l}\text { Definition of } \\
\text { control }\end{array}$ & $\begin{array}{l}\text { Control for important factor or } \\
\text { additional factor }\end{array}$ & $\begin{array}{l}\text { Exposure } \\
\text { assessment }\end{array}$ & $\begin{array}{l}\text { Same method of ascertainment } \\
\text { for cases and controls }\end{array}$ & $\begin{array}{l}\text { Nonresponse } \\
\text { rate }^{3}\end{array}$ & $\begin{array}{l}\text { Total } \\
\text { quality } \\
\text { scores }\end{array}$ \\
\hline $\begin{array}{l}\text { Kuper et al. } \\
{[11], 2000}\end{array}$ & $\star$ & $\star$ & - & $\star$ & $\star$ & - & $\star$ & - & 5 \\
\hline $\begin{array}{l}\text { Gallus et al. } \\
{[12], 2002}\end{array}$ & $\star$ & $\star$ & - & $\star$ & $\star$ & - & $\star$ & - & 6 \\
\hline $\begin{array}{l}\text { Gelatti et al. } \\
{[13], 2005}\end{array}$ & $\star$ & $\star$ & - & $\star$ & $\star \star$ & $\star$ & $\star$ & - & 7 \\
\hline $\begin{array}{l}\text { Ohfuji et al. } \\
{[14], 2006}\end{array}$ & $\star$ & $\star$ & - & $\star$ & $\star \star$ & - & $\star$ & - & 6 \\
\hline $\begin{array}{l}\text { Tanaka et al. } \\
{[15], 2007}\end{array}$ & $\star$ & $\star$ & $\star$ & $\star$ & $\star$ & - & $\star$ & - & 6 \\
\hline $\begin{array}{l}\text { Montella } \\
\text { et al. [16], } \\
2007\end{array}$ & $\star$ & $\star$ & - & $\star$ & $\star \star$ & - & $\star$ & - & 6 \\
\hline $\begin{array}{l}\text { Wakai et al. } \\
{[17], 2007}\end{array}$ & $\star$ & $\star$ & $\star$ & $\star$ & $\star$ & - & $\star$ & - & 6 \\
\hline $\begin{array}{l}\text { Ohish et al. } \\
{[18], 2008}\end{array}$ & $\star$ & $\star$ & $\star$ & $\star$ & $\star \star$ & - & $\star$ & - & 7 \\
\hline $\begin{array}{l}\text { Leung et al. } \\
{[19], 2011}\end{array}$ & $\star$ & $\star$ & - & $\star$ & - & $\star$ & $\star$ & - & 5 \\
\hline
\end{tabular}

${ }^{1}$ A study can be awarded a maximum of one star for each numbered item except for the item Control for most important factor or second important factor.

${ }^{2}$ A maximum of two stars can be awarded for Control for most important factor or second important factor. Studies that controlled for hepatitis B virus (HBV) or HCV infection received one star, whereas studies that controlled for alcohol drinking received one additional star.

One star was awarded if there was no significant difference in the response rate between control subjects and cases in the chi-square test $(P>0.05)$. 
Table 2 Quality assessment of cohort studies included in this meta- analysis ${ }^{1}$

\begin{tabular}{|c|c|c|c|c|c|c|c|c|c|}
\hline Study & $\begin{array}{l}\text { Representativeness } \\
\text { of the } \\
\text { exposed } \\
\text { cohort }\end{array}$ & $\begin{array}{l}\text { Selection } \\
\text { of the } \\
\text { unexposed } \\
\text { cohort }\end{array}$ & $\begin{array}{l}\text { Ascertainment } \\
\text { of exposure }\end{array}$ & $\begin{array}{l}\text { Outcome of } \\
\text { interest not } \\
\text { present at } \\
\text { start of } \\
\text { study }\end{array}$ & $\begin{array}{l}\text { Control for } \\
\text { important } \\
\text { factor or } \\
\text { additional } \\
\text { factor }^{2}\end{array}$ & $\begin{array}{l}\text { Outcome } \\
\text { assessment }\end{array}$ & $\begin{array}{l}\text { Follow-up } \\
\text { long } \\
\text { enough for } \\
\text { outcomes } \\
\text { to occur }{ }^{3}\end{array}$ & $\begin{array}{l}\text { Adequacy of } \\
\text { follow-up } \\
\text { of cohorts }\end{array}$ & $\begin{array}{l}\text { Total } \\
\text { quality } \\
\text { scores }\end{array}$ \\
\hline $\begin{array}{l}\text { Shimazu et al. } \\
{[20], 2005}\end{array}$ & $\star$ & $\star$ & $\star$ & $\star$ & $\star \star$ & $\star$ & $\star$ & $\star$ & 9 \\
\hline $\begin{array}{l}\text { Shimazu et al. } \\
{[20], 2005}\end{array}$ & $\star$ & $\star$ & $\star$ & $\star$ & $\star \star$ & $\star$ & $\star$ & $\star$ & 9 \\
\hline $\begin{array}{l}\text { Inoue et al. } \\
\text { [21], } 2005\end{array}$ & - & $\star$ & $\star$ & $\star$ & $\star$ & $\star$ & $\star$ & $\star$ & 7 \\
\hline $\begin{array}{l}\text { Kurozawa } \\
\text { et al. [22], } \\
2005\end{array}$ & $\star$ & $\star$ & $\star$ & $\star$ & $\star \star$ & $\star$ & $\star$ & - & 8 \\
\hline $\begin{array}{l}\text { Hu et al. [23], } \\
2008\end{array}$ & $\star$ & $\star$ & $\star$ & $\star$ & $\star \star$ & $\star$ & $\star$ & $\star$ & 9 \\
\hline $\begin{array}{l}\text { Inoue et al. } \\
\text { [24], } 2009\end{array}$ & - & $\star$ & $\star$ & $\star$ & $\star \star$ & $\star$ & $\star$ & $\star$ & 8 \\
\hline $\begin{array}{l}\text { Johnson et al. } \\
{[25], 2011}\end{array}$ & - & $\star$ & $\star$ & $\star$ & $\star$ & $\star$ & $\star$ & $\star$ & 7 \\
\hline
\end{tabular}

${ }^{1}$ A study can be awarded a maximum of one star for each numbered item except for the item Control for most important factor or second important factor. ${ }^{2}$ A maximum of two stars can be awarded for Control for most important factor or second important factor. Studies that controlled for HBV or HCV infection received one star, whereas studies that controlled for alcohol drinking received one additional star.

${ }^{3}$ A cohort study with a follow-up time $>7$ y was awarded one star.

${ }^{4}$ A cohort study with a follow-up rate $>75 \%$ was awarded one star.

outcome defined as liver cancer or hepatocellular carcinoma; and relative risk (RR) estimates, odds ratios (ORs) or hazard ratios (HRs) with their corresponding $95 \%$ confidence intervals (CIs). Exclusion criteria included duplicate reports and insufficient data about coffee consumption.

\section{Data extraction}

The following data were collected from each publication: the name of the first author, year of publication, the country where the study was conducted, sex, study design, study population demographics, study period,

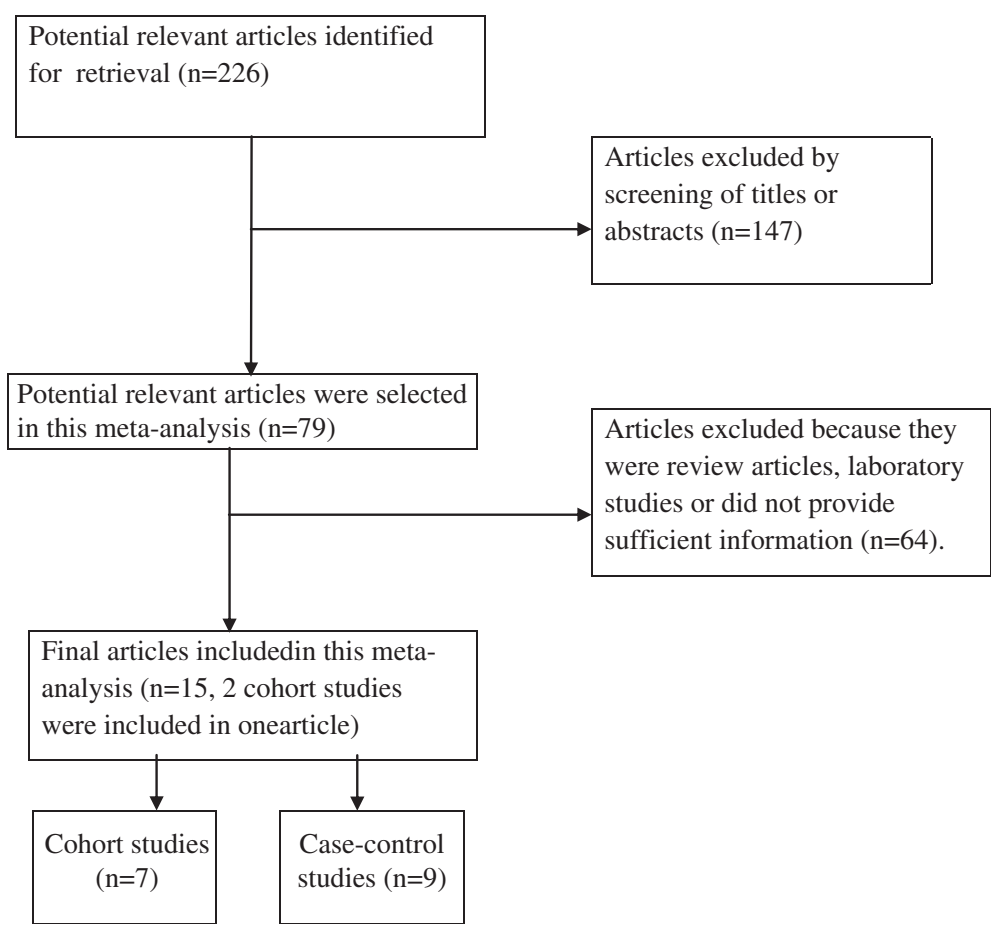

Figure 1 Process of study selection in the meta-analysis. 
Table 3 Characteristics of studies included in the meta-analysis

\begin{tabular}{|c|c|c|c|c|c|c|c|}
\hline Author & Design & $\begin{array}{l}\text { Study } \\
\text { population }\end{array}$ & Study period and outcome & Case/Control & Coffee consumption & $\begin{array}{l}\text { Risk estimate } \\
(95 \% \mathrm{Cl})\end{array}$ & Covariate adjustments \\
\hline \multirow[t]{3}{*}{ Kuper et al. [11], 2000} & \multirow[t]{3}{*}{$\mathrm{HCCS}$} & \multirow[t]{3}{*}{ Greece } & \multirow[t]{3}{*}{ 1995-1998 HCC incidence } & \multirow[t]{3}{*}{$333 / 360$} & Nondrinkers & 1 & \multirow{3}{*}{$\begin{array}{l}\text { Age, gender, years of schooling, HBsAg and/or } \\
\text { anti-HCV status }\end{array}$} \\
\hline & & & & & $<20$ cups/week & $1.1(0.5-2.6)$ & \\
\hline & & & & & $\geq 20$ cups/week & $0.9(0.4-2.5)$ & \\
\hline \multirow[t]{4}{*}{ Gallus et al. [12], 2002} & \multirow[t]{4}{*}{ HCCS } & \multirow[t]{4}{*}{ Greece Italy } & 1995-1998 & \multirow[t]{4}{*}{$834 / 1912$} & Nondrinkers & 1.0 & \multirow{4}{*}{$\begin{array}{l}\text { Age, sex, smoking, alcohol drinking, history of } \\
\text { diabetes or hepatitis, education, BMl }\end{array}$} \\
\hline & & & \multirow[t]{3}{*}{ 1984-1997 HCC incidence } & & 1 cup/day & $1.2(0.9-1.6)$ & \\
\hline & & & & & 2 cup/day & $1.0(0.7-1.3)$ & \\
\hline & & & & & $\geq 3$ cups/day & $0.7(0.5-1.0)$ & \\
\hline \multirow[t]{3}{*}{ Shimazu et al. [20], 2005} & \multirow[t]{3}{*}{ CS1 } & \multirow[t]{3}{*}{ Japan } & \multirow[t]{3}{*}{ 1984-1992 Primary liver cancer incidence } & \multirow[t]{3}{*}{$70 / 22404$} & Nondrinkers & 1.0 & \multirow{3}{*}{$\begin{array}{l}\text { Age, sex, smoking, alcohol drinking, history of } \\
\text { liver disease }\end{array}$} \\
\hline & & & & & occasionally & $0.56(0.33-0.97)$ & \\
\hline & & & & & $\geq 1$ cups/day & $0.53(0.28-1.00)$ & \\
\hline \multirow[t]{3}{*}{ Shimazu et al. [20], 2005} & \multirow[t]{3}{*}{ CS2 } & \multirow[t]{3}{*}{ Japan } & \multirow[t]{3}{*}{ 1990-1997 Primary liver cancer incidence } & \multirow[t]{3}{*}{$47 / 38703$} & Nondrinkers & 1.0 & \multirow{3}{*}{$\begin{array}{l}\text { Age, sex, smoking, alcohol drinking, history of } \\
\text { liver disease }\end{array}$} \\
\hline & & & & & occasionally & $1.05(0.52 \sim 2.16)$ & \\
\hline & & & & & $\geq 1$ cups/day & $0.68(0.31 \sim 1.51)$ & \\
\hline \multirow[t]{12}{*}{ Kurozawa et al. [22], 2005} & \multirow[t]{12}{*}{ CS } & \multirow[t]{12}{*}{ Japan } & \multirow[t]{12}{*}{ 1988-1999 HCC mortality } & \multirow[t]{12}{*}{ 258/83966 } & Total & & Age, sex, smoking, alcohol habits, history of \\
\hline & & & & & Nondrinkers & 1.0 & \\
\hline & & & & & $<1$ cup/day & $0.83(0.54-1.25)$ & \\
\hline & & & & & $\geq 1$ cup/day & $0.50(0.31-0.79)$ & \\
\hline & & & & & Men & & \\
\hline & & & & & Nondrinkers & 1.0 & \\
\hline & & & & & $<1$ cup/day & $0.91(0.57-1.45)$ & \\
\hline & & & & & $\geq 1$ cup/day & $0.49(0.28-0.85)$ & \\
\hline & & & & & Women & & \\
\hline & & & & & Nondrinkers & 1.0 & \\
\hline & & & & & $<1$ cup/day & $0.64(0.27-1.51)$ & \\
\hline & & & & & $\geq 1$ cup/day & $0.51(0.20-1.31)$ & \\
\hline Inoue et al. [21], 2005 & CS & Japan & 1990-2001 HCC incidence & $334 / 90452$ & Men and women & & Age, sex, study area, ethanol intake, green \\
\hline & & & & & Almost never & 1.0 & vegetable, green tea and smoking \\
\hline & & & & & 1-2 day/week & $0.75(0.56-1.01)$ & \\
\hline & & & & & 3-4 day/week & $0.79(0.55-1.14)$ & \\
\hline & & & & & $1-2$ cups/day & $0.52(0.38-0.73)$ & \\
\hline & & & & & 3-4 cups/day & $0.48(0.28-0.83)$ & \\
\hline & & & & & $\geq 5$ cups/day & $0.24(0.08-0.77)$ & \\
\hline
\end{tabular}




\begin{tabular}{|c|c|c|c|c|c|c|c|}
\hline & & & & & Men & & \\
\hline & & & & & Almost never & 1.0 & \\
\hline & & & & & 1-2 day/week & $0.74(0.52-1.05)$ & \\
\hline & & & & & 3-4 day/week & $0.76(0.50-1.16)$ & \\
\hline & & & & & $1-2$ cups/day & $0.55(0.38-0.80)$ & \\
\hline & & & & & $3-4$ cups/day & $0.41(0.21-0.77)$ & \\
\hline & & & & & $\geq 5$ cups/day & $0.27(0.09-0.87)$ & \\
\hline & & & & & women & & \\
\hline & & & & & Almost never & 1.0 & \\
\hline & & & & & 1-2 day/week & $0.77(0.43-1.37)$ & \\
\hline & & & & & 3-4 day/week & $0.89(0.43-1.84)$ & \\
\hline & & & & & $1-2$ cups/day & $0.43(0.20-0.90)$ & \\
\hline & & & & & 3-4 cups/day & $0.89(0.31-2.59)$ & \\
\hline & & & & & $\geq 5$ cups/day & -—- & \\
\hline Gelatti et al. [13], 2005 & HCCS & Italy & 1994-2003 HCC incidence & $250 / 500$ & Nondrinkers & 1.0 & Age, sex, alcohol drinking, HBV and/or HCV \\
\hline & & & & & $1-2$ cups/day & $0.8(0.4-1.3)$ & \\
\hline & & & & & $3-4$ cups/day & $0.4(0.2-0.8)$ & \\
\hline & & & & & $\geq 5$ cups/day & $0.3(0.1-0.7)$ & \\
\hline Ohfuji et al. [14], 2006 & HCCS & Japan & 2001-2002 HCC incidence & $73 / 253$ & Nondrinkers & 1.0 & Age, sex, smoking, alcohol drinking, time since \\
\hline & & & & & $<1$ cup/day & $0.61(0.18-2.03)$ & $\begin{array}{l}\text { IIrst Identification of IIver disease, BMI, disease } \\
\text { severity, family history of liver disease, }\end{array}$ \\
\hline & & & & & $\geq 1$ cup/day & $0.38(0.13-1.12)$ & interferon therapy \\
\hline Tanaka et al. [15], 2007 & PCCS & Japan & 2001-2004 HCC incidence & 209/1253 & Nondrinkers & 1.0 & Age, sex, smoking status, heavy alcohol \\
\hline & & & & & occasionally & $0.33(0.22 \sim 0.48)$ & \\
\hline & & & & & $1-2$ cups/day & $0.27(0.15 \sim 0.48)$ & \\
\hline & & & & & $\geq 3$ cups/day & $0.22(0.11 \sim 0.43)$ & \\
\hline Montella et al. [16], 2007 & HCCS & Italy & 1999-2002 HCC incidence & $185 / 412$ & Abstainers & $2.28(0.99-5.24)$ & Age, sex, alcohol drinking, HBV and/or HCV \\
\hline & & & & & $<14$ cups/week & 1.0 & ducation, smoking, alcohol drinking \\
\hline & & & & & 14-20 cups/week & $0.54(0.27-1.07)$ & \\
\hline & & & & & $21-27$ cups/week & $0.57(0.25-1.32)$ & \\
\hline & & & & & $\geq 28$ cups/week & $0.43(0.16-1.13)$ & \\
\hline Wakai et al. [17], 2007 & NCCS & Japan & 1988-1990 HCC incidence & $96 / 3444$ & Nondrinkers & 1.0 & Age, sex, smoking, alcohol drinking, \\
\hline & & & & & $<1$ cup/day & $0.77(0.45-1.32)$ & $\begin{array}{l}\text { consumption of areca,educational levels, } \\
\text { ethnicity,source of hospital }\end{array}$ \\
\hline & & & & & $\geq 1$ cup/day & $0.49(0.25-0.96)$ & \\
\hline
\end{tabular}


Table $\mathbf{3}$ Characteristics of studies included in the meta-analysis (Continued)

\begin{tabular}{|c|c|c|c|c|c|c|c|}
\hline \multirow[t]{18}{*}{ Hu et al. [23], 2008} & \multirow[t]{18}{*}{ CS } & \multirow[t]{18}{*}{ Finland } & \multirow[t]{18}{*}{ 1997-2002 HCC incidence } & \multirow[t]{18}{*}{$128 / 60323$} & Total & & \multirow{18}{*}{$\begin{array}{l}\text { Age, sex, smoking, alcohol drinking, education, } \\
\text { study year, diabetes and chronic liver disease } \\
\text { BMI and during follow up. }\end{array}$} \\
\hline & & & & & 0-1 cup/day & 1.0 & \\
\hline & & & & & 2-3 cups/day & $0.66(0.37-1.16)$ & \\
\hline & & & & & 4-5 cups/day & $0.44(0.25-0.77)$ & \\
\hline & & & & & 6-7 cups/day & $0.38(0.21-0.69)$ & \\
\hline & & & & & $\geq 8$ cups/day & $0.32(0.16 \sim 0.62)$ & \\
\hline & & & & & Men & & \\
\hline & & & & & 0-1 cup/day & 1.0 & \\
\hline & & & & & 2-3 cups/day & $0.68(0.35-1.31)$ & \\
\hline & & & & & 4-5 cups/day & $0.35(0.18-0.71)$ & \\
\hline & & & & & 6-7 cups/day & $0.31(0.15-0.63)$ & \\
\hline & & & & & $\geq 8$ cups/day & $0.28(0.13-0.61)$ & \\
\hline & & & & & Women & & \\
\hline & & & & & 0-1 cup/day & 1.0 & \\
\hline & & & & & 2-3 cups/day & $0.62(0.19-2.04)$ & \\
\hline & & & & & 4-5 cups/day & $0.60(0.20-1.82)$ & \\
\hline & & & & & 6-7 cups/day & $0.58(0.19-1.82)$ & \\
\hline & & & & & $\geq 8$ cups/day & $0.41(0.10-1.70)$ & \\
\hline \multirow[t]{2}{*}{ Ohishi et al. [18], 2008} & \multirow[t]{2}{*}{ NCCS } & \multirow[t]{2}{*}{ Japan } & \multirow[t]{2}{*}{ 1999-2002 HCC incidence } & \multirow[t]{2}{*}{$224 / 644$} & Nondrinkers & 1.0 & \multirow{2}{*}{$\begin{array}{l}\text { Hepatitis virus infection, alcohol consumption, } \\
\text { smoking habits, BMl, diabetes mellitus, and } \\
\text { radiation dose to the liver }\end{array}$} \\
\hline & & & & & Daily & $0.40(0.16-1.02)$ & \\
\hline \multirow[t]{13}{*}{ Inoue et al. [24], 2009} & \multirow[t]{13}{*}{ CS } & \multirow[t]{13}{*}{ Japan } & \multirow[t]{13}{*}{ 1993-1994 HCC incidence } & \multirow[t]{13}{*}{$110 / 18815$} & Total & & \multirow{13}{*}{$\begin{array}{l}\text { Age, sex, area, smoking, alcohol drinking, BMI, } \\
\text { diabetes mellitus, green tea consumption, } \\
\text { serum ALTlevel, and HBV and HCV infection } \\
\text { status }\end{array}$} \\
\hline & & & & & Almost never & 1.0 & \\
\hline & & & & & $<1$ cup/day & $0.67(0.42-1.07)$ & \\
\hline & & & & & 1-2 cups/day & $0.49(0.27-0.91)$ & \\
\hline & & & & & $\geq 3$ cups/day & $0.54(0.21-1.39)$ & \\
\hline & & & & & Men & & \\
\hline & & & & & Almost never & 1.0 & \\
\hline & & & & & $<1$ cup/day & $0.79(0.46-1.37)$ & \\
\hline & & & & & 1-2 cups/day & $0.37(0.17-0.81)$ & \\
\hline & & & & & $\geq 3$ cups/day & $0.32(0.10-1.10)$ & \\
\hline & & & & & Women & & \\
\hline & & & & & Almost never & 1.0 & \\
\hline & & & & & $<1$ cup/day & $0.39(0.15-1.03)$ & \\
\hline
\end{tabular}


Table 3 Characteristics of studies included in the meta-analysis (Continued)

\begin{tabular}{|c|c|c|c|c|c|c|c|}
\hline & & & & & $1-2$ cups/day & $0.92(0.36-2.38)$ & \\
\hline & & & & & $\geq 3$ cups/day & $0.69(0.11-4.22)$ & \\
\hline \multirow[t]{5}{*}{ Johnson et al. [25], 2011} & \multirow[t]{5}{*}{ CS } & \multirow[t]{5}{*}{ Chinese } & \multirow[t]{5}{*}{ 1993-2006 HCC incidence } & \multirow[t]{5}{*}{$362 / 61321$} & Nondrinkers & 1.0 & \multirow{5}{*}{$\begin{array}{l}\text { Age at recruitment, sex, dialect group, } \\
\text { year of recruitment, BMl, level of education, } \\
\text { consumption of alcoholic beverages, } \\
\text { smoking, black tea and green tea intake, } \\
\text { and history of diabetes. }\end{array}$} \\
\hline & & & & & $0-<1$ drinkers/day & $0.94(0.63-1.40)$ & \\
\hline & & & & & $1-<2$ drinkers/day & $1.17(0.87-1.56)$ & \\
\hline & & & & & $2-<3$ drinkers/day & $0.78(0.56-1.07)$ & \\
\hline & & & & & $\geq 3$ drinkers/day & $0.56(0.31-1.00)$ & \\
\hline \multirow[t]{3}{*}{ Leung et al. [19], 2011} & \multirow[t]{3}{*}{ HCCS } & \multirow[t]{3}{*}{ HongKong } & \multirow[t]{3}{*}{ 2007-2008 HCC incidence } & \multirow[t]{3}{*}{$109 / 125$} & $<1$ time/week & 1.0 & \multirow{3}{*}{$\begin{array}{l}\text { Age, sex, alcohol drinking, cigarette smoking, } \\
\text { tea consumption and physical activity }\end{array}$} \\
\hline & & & & & 1-3 times/week & $0.58(0.24-1.36)$ & \\
\hline & & & & & $\geq 4$ times/week & $0.41(0.19-0.89)$ & \\
\hline
\end{tabular}

ALT: alanine aminotransferase; BMI: body mass index; Cl: confidence interval; HbsAg: hepatitis B surface antigen; HCCS: hospital-based case-control study; PCCS: population-based case-control study; NCCS: nested case-control study; CS: cohort study; HCC: hepatocellular carcinoma. 


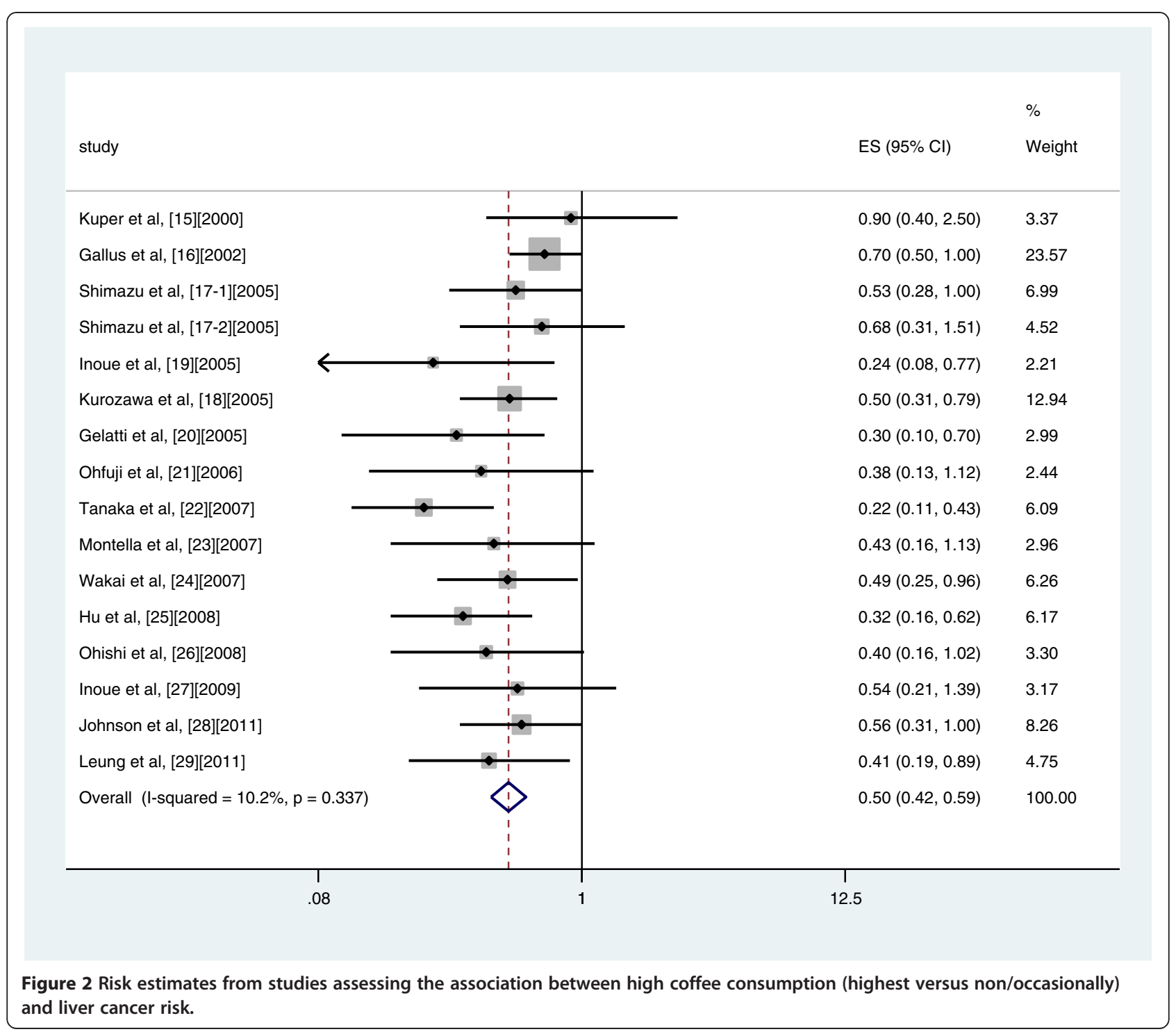

sample size, type of outcome, consumption of coffee, number of exposed cases, the RRs or ORs or HRs and their 95\%CIs, and covariates adjusted in the analysis. All data were extracted independently by three reviewers, and any disagreement was resolved by discussion between them. If results were published more than once, the results from the most recent one were selected. Because liver cancer is rare, the OR was assumed to be the same as RR and HR, and all results are reported as OR for simplicity [9].

\section{Quality assessment}

The study quality was assessed by the 9-star NewcastleOttawa Scale [10]. A full score is 9 stars, and a score $\geq 6$ stars is considered to be high quality. The quality of case-control studies was assessed as follows: adequate definition of cases, representativeness of cases, selection of controls, definition of controls, control for the most important factor or the second important factor, exposure assessment, same method of ascertainment for all subjects, and non-response rate (Table 1). The quality of cohort studies was assessed as follows: representativeness of the exposed cohort, selection of the unexposed cohort, ascertainment of exposure, outcome of interest not present at start of study, control for the most important factor or the second important factor, outcome assessment, follow-up long enough for outcomes to occur, adequacy of follow-up of cohorts (Table 2).

\section{Statistical analysis}

For the included studies, we determined pooled ORs (or RRs or HRs) with 95\% CI for the highest versus lowest category of coffee consumption from each study. Since various sources of heterogeneity may exist owing 
to a variety of factors, we carried out subgroup analysis to investigate the influence of study design, study region, sex and history of liver disease on the heterogeneity.

Statistical heterogeneity was evaluated through the $\mathrm{Q}$ test and $\mathrm{I}^{2}$ statistic [26]; $P<0.10$ was considered statistically significant [27]. If the heterogeneity was acceptable $\left(\mathrm{I}^{2}<50 \%\right)$, a fixed effects analysis was conducted to calculate the pooled OR. In addition, a random effects model was used. The causes of heterogeneity were investigated by subgroup analyses. To evaluate whether publication bias might affect the statistical results, we applied Egger's test and Begg's method to assess bias through visual inspection of funnel plots [28,29]; all statistical analyses were conducted using STATA (version 11.0; StataCorp, College Station, TX, USA). All statistical tests were 2 -sided.

\section{Results}

\section{Study characteristics}

Figure 1 shows the process of selecting studies for the meta-analysis. Sixteen observational articles examining the association between coffee consumption and the risk of liver cancer were included in our meta-analysis (Table 3) [11-25]. There were nine case-control studies [11-19] and seven cohort studies (two of these were nested in a cohort article) [20-25]. Of the selected studies, 11 were conducted in Asia (nine in Japan $[14,15,17,18,20-22,24]$, one in Singapore [25], one in Hong Kong [19]) and five in Europe (one in Finland [23], two in Italy $[13,16]$, one in Greece [11], one in Italy and Greece [12]). Among case-control studies, seven were hospital-based case-control studies [11-16,19], and two were nested case- control studies $[17,18]$.

\section{High vs Non/Almost never drinkers}

A meta-analysis of risk estimates for the incidence of liver cancer for highest compared with lowest coffee consumption categories could be conducted with data from nine case-control studies and nine cohort studies. Our results showed a $50 \%$ reduction in risk of liver cancer with the highest intake of coffee (summary OR: 0.50, 95\%CI: 0.42-0.59) (Figure 2). There was no significant heterogeneity across studies $\left(\mathrm{Q}=16.71, P=0.337, \mathrm{I}^{2}=\right.$ $10.2 \%)$. There was a symmetric funnel plot and no evidence of significant publication bias from Egger's test $(P=0.05)$ and Begg's test $(P=0.096)$ (Figure 3$)$.

A sensitivity analysis for the risk of liver cancer was performed by excluding one study [22], the outcome of which was mortality. The summary OR was 0.49 (95\% CI: $0.41-0.59)$. There was no significant heterogeneity across studies $\left(\mathrm{Q}=16.7, P=0.272, \mathrm{I}^{2}=16.2 \%\right)$.

Similar results were found in a subgroup analyses conducted by study design in case-control studies (OR: $0.50,95 \%$ CI: $0.40-0.63, \mathrm{Q}=12.38, P=0.125, \mathrm{I}^{2}=$ $36.8 \%$ ), and cohort studies (OR: $0.48,95 \%$ CI: 0.38-0.62, $\mathrm{Q}=2.47, P=0.676, \mathrm{I}^{2}=0.0 \%$ ) (Figure 4 ).

In a subgroup analysis conducted by sex, only four studies were included in the analysis: studies in males gave an OR of 0.38 (95\% CI: $0.25-0.56, Q=$ $1.83, P=0.609, \mathrm{I}^{2}=0.0 \%$ ), while studies in females gave an OR of 0.60 (95\% CI: $0.33-1.10, \mathrm{Q}=0.94, P=0.815$, $\left.\mathrm{I}^{2}=0.0 \%\right)$ (Table 4).

When stratified analysis was conducted by study region, a statistically significant protective effect of coffee consumption on liver cancer was observed in Asia

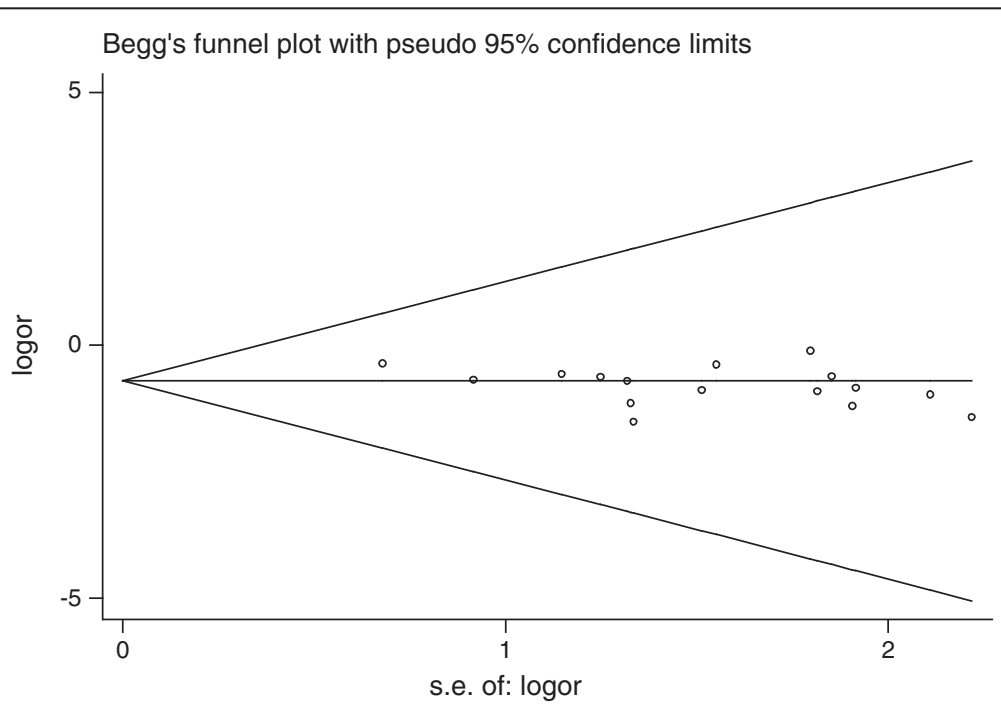

Figure 3 Begg's funnel plot of coffee consumption and risk of liver cancer. 


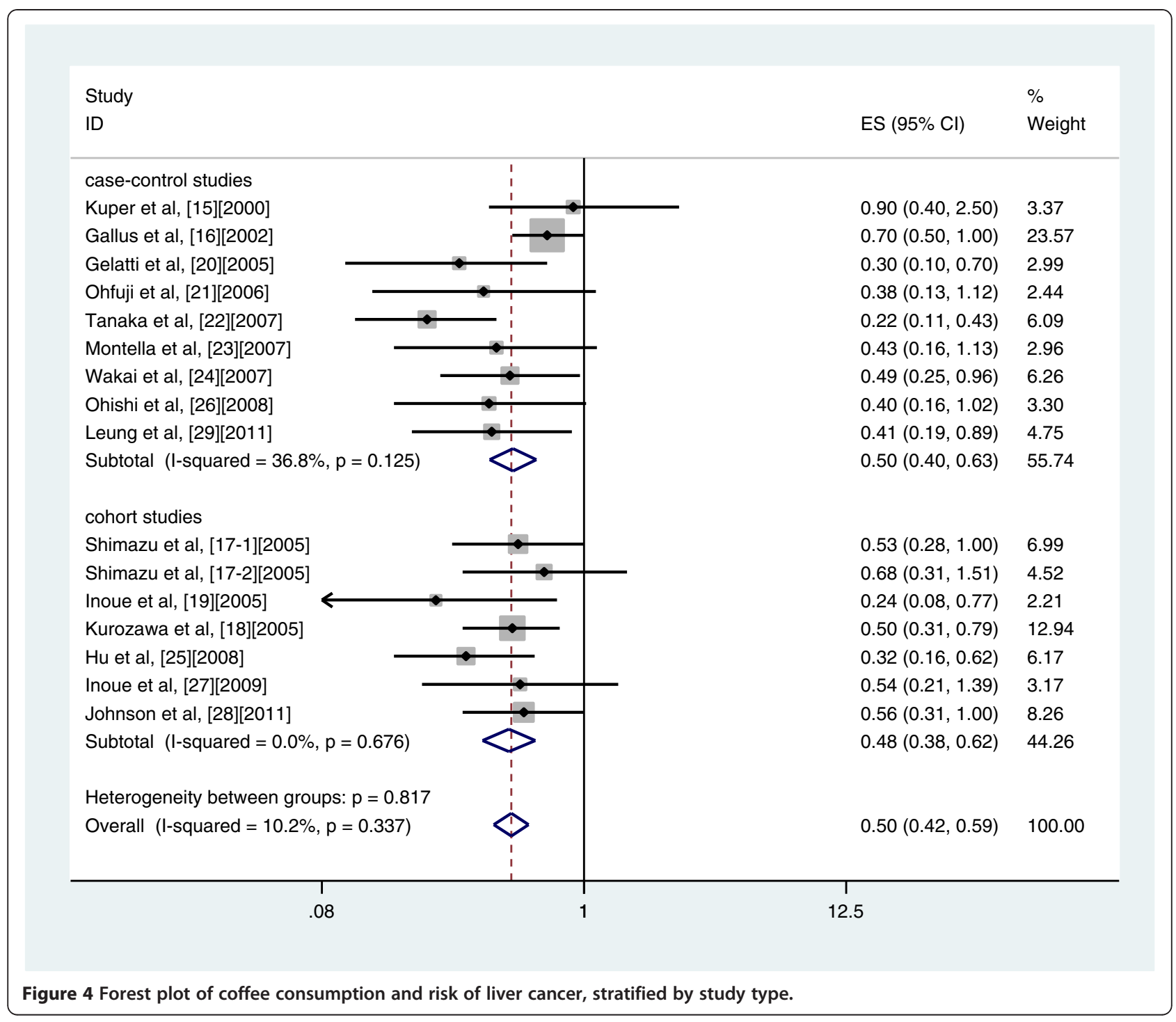

(OR: $0.45,95 \%$ CI: $0.36-0.56, \mathrm{Q}=7.86, P=0.642, \mathrm{I}^{2}=$ 0.0\%), and in Europe (OR: 0.57, 95\% CI: 0.44-0.75, Q = 7.09, $P=0.131, \mathrm{I}^{2}=43.6 \%$ ) (Figure 5).

Stratification analysis was conducted without or with adjustment for a history of liver disease. A statistically significant protective effect of coffee consumption on liver cancer was observed with no adjustment for a history of liver disease (OR: 0.39, 95\% CI: 0.28-0.54, $\left.\mathrm{Q}=5.34, P=0.254, \mathrm{I}^{2}=25.1 \%\right)$ and after adjustment for a history of liver disease (OR: 0.54, 95\% CI: 0.46-0.66, $\left.\mathrm{Q}=8.5, \mathrm{P}=0.581, \mathrm{I}^{2}=0.0 \%\right)$.

\section{Discussion}

Coffee consumption has been suggested as a protective factor in the development of liver cancer, but evidence from observational studies is inconsistent [11-25]. The results of the current meta-analysis of seven prospective and nine case-control studies suggest that there is an inverse association between coffee consumption and liver cancer among different groups according to consumption level. There were significant reductions of $50 \%$ in the risk of liver cancer with the highest consumption of coffee compared with non/almost never consumption. The metaanalyses of Bravi et al. [30] found significant reductions of $55 \%$ in the risk of liver cancer with the high drinkers compared with non-drinkers, and Larsson \& wolk [31] found a risk reduction of $43 \%$ per 2 cups of coffee per day increment. Our results are consistent with these two previous articles, partly because all of the studies in these two articles are included in the our meta-analysis.

Some results in this meta-analysis were heterogeneous, because the included studies had differences in study design, study region, study sex distribution, and 
Table 4 Pooled relative risks and $95 \% \mathrm{Cl}$ for coffee consumption and liver cancer risk

\begin{tabular}{|c|c|c|c|c|c|c|}
\hline \multirow[t]{2}{*}{ Study } & \multirow{2}{*}{$\begin{array}{l}\text { No. of } \\
\text { studies }\end{array}$} & \multirow{2}{*}{$\begin{array}{l}\text { No. of } \\
\text { cases }\end{array}$} & \multirow{2}{*}{$\begin{array}{l}\text { Relative risk } \\
(95 \% \mathrm{Cl})\end{array}$} & \multicolumn{3}{|c|}{ Heterogeneity } \\
\hline & & & & $\mathbf{Q}$ & $P$ & $I^{2}(\%)$ \\
\hline \multicolumn{7}{|c|}{ High versus non/almost never intake } \\
\hline All studies & 16 & 3,622 & $0.50(0.42-0.59)$ & 16.71 & 0.337 & $10.2 \%$ \\
\hline \multicolumn{7}{|l|}{ Study design } \\
\hline Cohort studies & 7 & 1,309 & $0.48(0.38-0.62)$ & 2.47 & 0.676 & $0.0 \%$ \\
\hline Case-control studies & 9 & 2,313 & $0.50(0.40-0.63)$ & 12.38 & 0.125 & $36.8 \%$ \\
\hline \multicolumn{7}{|l|}{ Study region } \\
\hline Asia & 11 & 1,892 & $0.45(0.36-0.56)$ & 7.86 & 0.642 & $0.0 \%$ \\
\hline Europe & 5 & 1,730 & $0.57(0.44-0.75)$ & 7.09 & 0.131 & $43.6 \%$ \\
\hline \multicolumn{7}{|l|}{ Study gender } \\
\hline Male & 4 & 583 & $0.38(0.25-0.56)$ & 1.83 & 0.609 & $0.0 \%$ \\
\hline Female & 4 & 247 & $0.60(0.33-1.10)$ & 0.94 & 0.815 & $0.0 \%$ \\
\hline \multicolumn{7}{|c|}{ Adjustment for main confounders ${ }^{a}$} \\
\hline Adjusted & 11 & 2,512 & $0.54(0.46-0.66)$ & 8.5 & 0.581 & $0.0 \%$ \\
\hline Unadjusted & 5 & 1,110 & $0.39(0.28-0.54)$ & 5.34 & 0.254 & $25.1 \%$ \\
\hline
\end{tabular}

${ }^{a}$ main confounder: hepatitis B and hepatitis C virus infection or history of liver disease.

control for confounding factors. In separate analyses by study design, we found an inverse association between coffee consumption and liver cancer among hospital- based case-control studies and among cohort studies.

There was also an inverse association between coffee consumption and liver cancer among European and Asian populations, and the significant risk reduction was stronger among Asian than European populations. The different results may be explained by racial differences. Differences in coffee drinking habits may be a partial explanation for the discrepancy.

We also found an inverse association between coffee consumption and liver cancer among male and female populations, but this result was derived from only four studies with a small number of cases, so we could not draw a firm conclusion. A history of liver disease may be a risk factor for liver cancer, and after adjustment for this, a significant inverse association remained between coffee consumption and liver cancer among two subgroups.

There are several potential mechanisms through which high consumption of coffee may reduce the risk of liver cancer. Coffee contains a variety of chemicals including caffeine, cafestol, kahweol, and chlorogenic acids. It remains uncertain which ingredient of coffee is protective against liver cancer. Some studies have indicated that caffeine can prevent oxidative DNA damage, modify the apoptotic response and reverse cell cycle checkpoint function [32-34]. Caffeine has strong antioxidant properties [35]. In an animal experiment, caffeine significantly reduced the incidence of chemically-induced hepatocellular carcinoma in rats [36]. Furthermore, cafestol and kahweol have been shown to be anticarcinogenic [37,38]. Cafestol and kahweol have demonstrated a protective effect against aflatoxin B1induced genotoxicity [39]. In addition, a study by Feng et al. showed that chlorogenic acids can scavenge reactive oxygen species and have an anti-tumor effect [40]. These studies suggest that ingredients in coffee may play an important role in protecting against the occurrence and development of liver cancer.

Our meta-analysis had some merits. First, the total number of cases included in this meta-analysis was substantial ( $\mathrm{n}=3622$ liver cancer cases). The summary ORs of the highest compared with the lowest coffee consumption categories for risk of liver cancer were consistent with those in a previously published meta-analyses $(n=2260$ liver cancer cases) [30,31]. Second, we found little evidence of publication bias in our meta-analysis. Third, we performed a comprehensive search of the literature on the association between coffee consumption and liver cancer risk up to May 2012.

Our meta-analysis had several limitations. First, we used the highest and lowest coffee consumption levels as measures of exposure, but we were not able to determine whether different amounts of coffee consumption could decrease liver cancer risk. Second, misclassification bias should be considered. Each study presented coffee consumption in different units (cups/week, cups/ day, days/week, drinks/day, times/week). Therefore, differential misclassification could bias the results. 


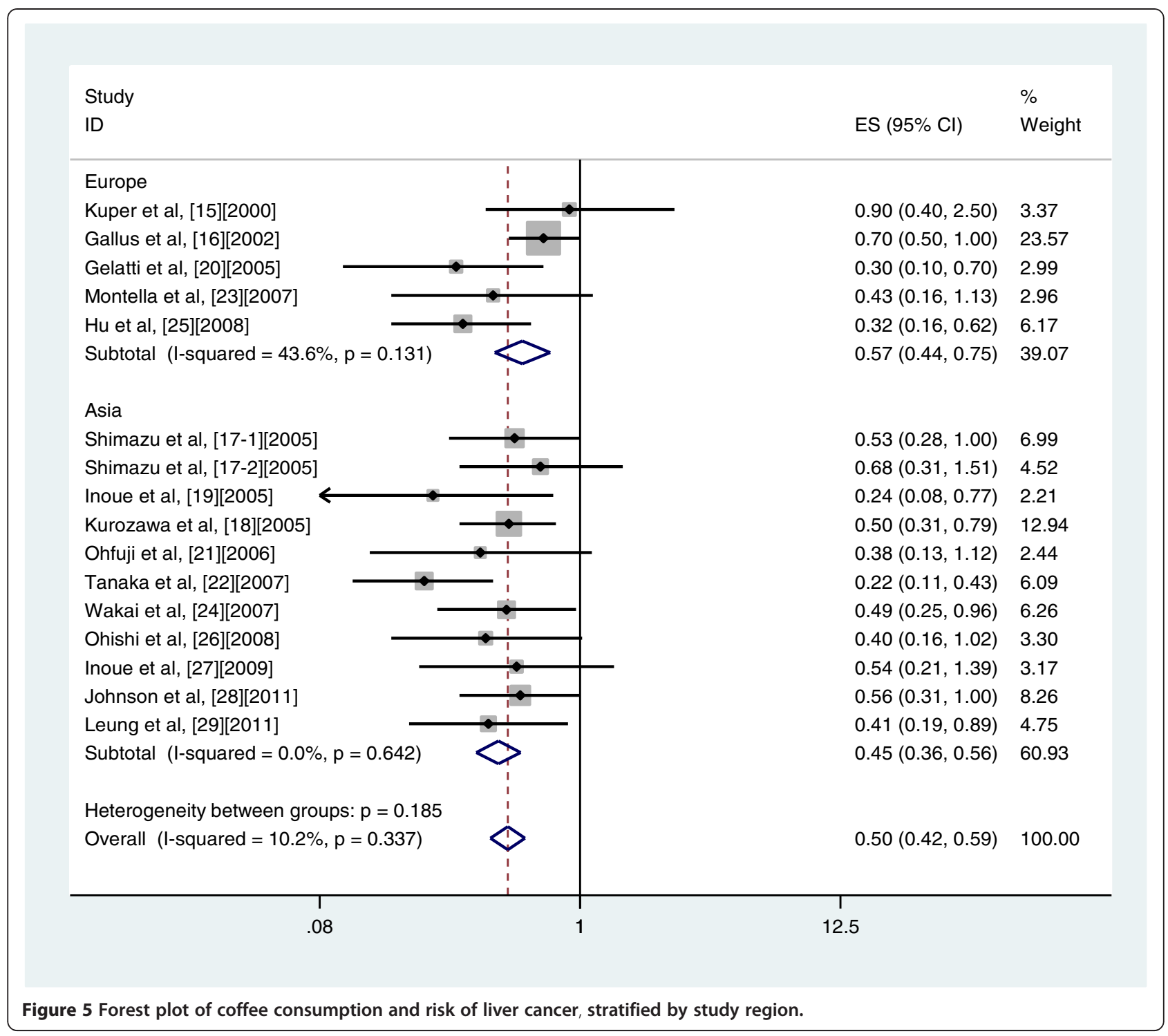

Third, because liver cancer is a multifactorial disease, it is uncertain whether other factors may have influenced the results. Fourth, the study areas covered in our meta-analysis only included Asia (Japan, China, Hong Kong) and Europe (Finland, Greece, Italy). Therefore, the value of our results is limited for other areas (Africa, America and Australia). Fifth, potential publication bias might have influenced the results, despite no bias indicated from either the funnel plot or Egger's test.

\section{Conclusion}

The results of this meta-analysis suggested that coffee consumption may be associated with a reduced risk of liver cancer. However, because of potential confounding, this finding should be treated with caution. Further bettercontrolled studies are needed to confirm this finding.

Competing interests

The authors declare no potential conflict of interest relevant to this research.

\section{Authors' contributions}

LXS and BC designed the research; LXS and XHL performed the literature search; LXS, XHL and MJ analyzed the data and interpreted the results; LXS and $\mathrm{BC}$ wrote the paper; all authors approved the final manuscript.

\section{Acknowledgements}

This study was funded by Science and Technology Program of Shenyang (No. f12-277-1-54).

\section{Author details}

${ }^{1}$ Department of Cadre Ward II, First Affiliated Hospital of China Medical University, No.155, Nanjing North Street, Heping District, Shenyang, Liaoning Province 110001, China. ${ }^{2}$ Department of Gastroenterology, First Affiliated Hospital of China Medical University, No.155, Nanjing North Street, Heping 
District, Shenyang, Liaoning Province 110001, China. ${ }^{3}$ Department of General Surgery, First Affiliated Hospital of China Medical University, No.155, Nanjing North Street, Heping District, Shenyang, Liaoning Province 110001, China.

Received: 18 July 2012 Accepted: 21 February 2013

Published: 25 February 2013

\section{References}

1. Ferlay J, Bray F, Pisani P, et al: GLOBOCAN 2002: Cancer Incidence, Mortality, and Prevalence Worldwide, IARC CancerBase No. 5. version 2.0. Lyon, France: International Agency for Cancer Research 2004.

2. Stewart BW, Kleihues P: World cancer report. Lyon: IARC Press: Stewart BW, Kleihues P; 2003.

3. Srivatanakul $P$, Spriplung $H$, Deerasamee S: Epidemiology of liver cancer: an overview. Asian Pacific J Cancer Prev 2004, 5:118-125.

4. Llovet JM, Burroughs A, Bruix J: Hepatocellular carcinoma. Lancet 2003, 362:1907-1917.

5. Franceschi S, Montella M, Polesel J, et al: Hepatitis viruses, alcohol and tobacco in the etiology of hepatocellular carcinoma in Italy. Cancer Epidemiol Biomarkers Prev 2006, 15:683-689.

6. Yu MC, Yuan JM: Environmental factors and risk for hepatocellular carcinoma. Gastroenterology 2004, 127(Suppl 1):S72-S78.

7. Kiyosawa K, Umemura T, Ichijo T, et al: Hepatocellular carcinoma: Recent trends in Japan. Gastroenterology 2004, 127(suppl 1):S17-S26.

8. Aizawa Y, Shibamoto Y, Takagi I, et al: Analysis of factors affecting the appearance of hepatocellular carcinoma in patients with chronic hepatitis C.A long term follow-up study after histologic diagnosis. Cancer 2000, 89:53-59.

9. Greenland S: Quantitative methods in the review of epidemiologic literature. Epidemiol Rev 1987, 9:1-30

10. Wells GA, Shea B, O'Connell D, et al: The Newcastle-Ottawa Scale (NOS) for assessing the quality of nonrandomised studies in the meta-analysis. Available from; 2011. http://www.ohri.ca/programs/clinical_epidemiology/oxford.asp (cited 19 March 2011).

11. Kuper $\mathrm{H}$, Tzonou A, Kaklamani $\mathrm{E}$, et al: Tobacco smoking, alcohol consumption and their interaction in the causation of hepatocellular carcinoma. Int I Cancer 2000, 85:498-502.

12. Gallus S, Bertuzzi M, Tavani A, et al: Does coffee protect against hepatocellular carcinoma? Br J Cancer 2002, 87:956-959.

13. Gelatti U, Covolo L, Franceschini M, et al: Coffee consumption reduces the risk of hepatocellular carcinoma independently of its aetiology: a casecontrol study. J Hepatol 2005, 42:528-534

14. Ohfuji S, Fukushima W, Tanaka T, et al: Coffee consumption and reduced risk of hepatocellular carcinoma among patients with chronic type $C$ liver disease: a case-control study. Hepatol Res 2006, 36:201-208.

15. Tanaka K, Hara M, Sakamoto T, et al: Inverse association between coffee drinking and the risk of hepatocellular carcinoma:a case-control study in Japan. Cancer Sci 2007, 98:214-218.

16. Montella M, Polesel J, La Vecchia C, et al: Coffee and tea consumption and risk of hepatocellular carcinoma in Italy. Int I Cancer 2007, 120:1555-1559.

17. Wakai K, Kurozawa Y, Shibata A, et al: Liver cancer risk, coffee, and hepatitis C virus infection: a nested case-control study in Japan. $\mathrm{Br} J$ Cancer 2007, 97:426-428

18. Ohishi W, Fujiwara S, Cologne JB, et al: Risk factors for hepatocellular carcinoma in a Japanese population: a nested case-control study. Cancer Epidemiol Biomarkers Prev 2008, 17:846-854.

19. Leung WW, Ho SC, Chan HL, et al: Moderate coffee consumption reduces the risk of hepatocellular carcinoma in hepatitis B chronic carriers: a case- control study. J Epidemiol Community Health 2011, 65:556-558.

20. Shimazu T, Tsubono Y, Kuriyama S, et al: Coffee consumption and the risk of primary liver cancer: pooled analysis of two prospective studies in Japan. Int J Cancer 2005, 116:150-154.

21. Inoue M, Yoshimi I, Sobue T, et al: Influence of coffee drinking on subsequent risk of hepatocellular carcinoma: a prospective study in Japan. J Natl Cancer Inst 2005, 97:293-300

22. Kurozawa $Y$, Ogimoto I, Shibata A et al. Coffee and risk of death from hepatocellular carcinoma in a large cohort study in Japan. $\mathrm{Br} J$ Cancer 2005, 93:607-610.

23. Hu G, Tuomilehto J, Pukkala E, et al: Joint effects of coffee consumption and serum gam-ma-glutamyltransferase on the risk of liver cancer. Hepatology 2008, 48:129-136.
24. Inoue $\mathrm{M}$, Kurahashi $\mathrm{N}$, Iwasaki $\mathrm{M}$, et al: Effect of coffee and green tea consumption on the risk of liver cancer:cohort analysis by hepatitis virus infection status. Cancer Epidemiol Biomarkers Prev 2009, 18:1746-1753

25. Johnson S, Koh WP, Wang R, et al: Coffee consumption and reduced risk of hepatocellular carcinoma:findings from the Singapore Chinese Health Study. Cancer Causes Control 2011, 22:503-510.

26. Higgins JP, Thompson SG: Quantifying heterogeneity in a meta-analysis. Stat Med 2002, 21:1539-1558.

27. Hedges LV, Pigott TD: The power of statistical tests in meta-analysis. Psychol Methods 2001, 6:203-217.

28. Begg $\mathrm{CB}$, Mazumdar M: Operating characteristics of a rank correlation test for publication bias. Biometrics 1994, 50:1088-1101.

29. Egger M, Smith GD: Bias in location and selection of studies. BMJ 1998 316:61-66

30. Bravi F, Bosetti C, Tavani A, et al: Coffee drinking and hepatocellular carcinoma risk: a meta-analysis. Hepatology 2007, 46:430-435.

31. Larsson SC, Wolk A: Coffee consumption and risk of liver cancer: a meta- analysis. Gastroenterology 2007, 132:1740-1745.

32. Asaad NA, Zeng ZC, Guan J, et al: Homologousre combination as a potential Target for caffeine radiosensitization in mammalian cells: reduced caffeine radio sensitizationin XRCC2 and XRCC3 mutants. Oncogene 2000, 19:5788-5800.

33. Saiki S, Sasazawa Y, Imamichi $Y$, et al: Caffeine induces apoptosis by enhancemen t of autophagy via PI3K/Akt/mTOR/p70S6K inhibition. Autophagy 2011, 7:176-187.

34. Joerges C, Kuntze I, Herzinger T: Induction of a caffeine-sensitive S-phase cell cycle checkpoint by psoralen plus ultraviolet A radiation. Oncogene 2003, 22:6119-6128.

35. Azam S, Hadi N, Khan NU, et al: Antioxidant and prooxidant properties of caffeine, theobromine and xanthine. Med Sci Monit 2003, 9:BR325-BR330

36. Hosaka S, Kawa S, Aoki Y, et al: Hepatocarcinogenesis inhibition by caffeine in $\mathrm{ACl}$ rats treated with 2-acetylaminofluorene. Food Chem Toxicol 2001, 39:557-561.

37. Cavin C, Holzhaeuser D, Scharf G, et al: Cafestol and kahweol, two coffee specific diterpenes with anticarcino-Genic activity. Food Chem Toxicol 2002, 40:1155-1163.

38. Majer BJ, Hofer E, Cavin C, et al: Coffee diterpenes prevent the genotoxic effects of 2-amino-1-methyl-6-phenylimidazo[4,5-b]pyridine(PhIP)and $\mathrm{N}$-nitro- Sodimethylamine in a human derived liver cell line(HepG2). Food Chem Toxicol 2005, 43:433-441.

39. Cavin C, Holzhauser D, Constable A, et al: The coffee-specific diterpenes cafestol and kahweol protect against afla-toxinB1-induced genotoxicity through a dual mechanism. Carcinogenesis 1998, 19:75-1369.

40. Feng R, Lu Y, Bowman LL, et al: Inhibition of activator protein-1, NF-kappaB, and MAPKs and induction of phase 2 detoxifying enzyme activity by chlorogenic acid. J Biol Chem 2005, 280:27888-27895.

doi:10.1186/1471-230X-13-34

Cite this article as: Sang et al:: Consumption of coffee associated with reduced risk of liver cancer: a meta-analysis. BMC Gastroenterology 2013 13:34.

\section{Submit your next manuscript to BioMed Central and take full advantage of:}

- Convenient online submission

- Thorough peer review

- No space constraints or color figure charges

- Immediate publication on acceptance

- Inclusion in PubMed, CAS, Scopus and Google Scholar

- Research which is freely available for redistribution 